\title{
Ionospheric weather: cloning missed foF2 observations for derivation of variability index
}

\author{
T. L. Gulyaeva ${ }^{1,2}$, I. Stanislwska ${ }^{2}$, and M. Tomasik ${ }^{2}$ \\ ${ }^{1}$ IZMIRAN, 142190 Troitsk, Moscow Region, Russia \\ ${ }^{2}$ Space Research Centre PAS, Bartycka 18-A, 00-716 Warsaw, Poland
}

Received: 16 January 2007 - Revised: 22 October 2007 - Accepted: 22 October 2007 - Published: 26 February 2008

\begin{abstract}
A techique for filling the gaps of the missing F2-layer critical frequency is proposed and applied for the derivation of the ionospheric weather index, characterizing the degree of disturbance at each particular station. A dailyhourly analysis of ionosonde observations of foF 2 for 16 stations at latitude range $37^{\circ}$ to $70^{\circ} \mathrm{N}$, longitudes of $10^{\circ} \mathrm{W}$ to $150^{\circ} \mathrm{E}$, is performed during the solar minimum, 2006 . Missed ionosonde observations are reconstructed by cloning data of another station. The process of gap filling considers hourly values of the F peak density $\mathrm{NmF} 2$ (deduced from foF2), normalized to the respective median, and assumes that this ratio remains the same for the parent and cloned data. It is shown that the correlation coefficient between cloned fcF2 and observed foF 2 is greater than 0.75 for the positive and negative ionospheric disturbed days during a year at solar minimum, independent of the distance between the stations in high and middle latitudes. The quiet reference is determined as a running daily-hourly median for 27 days, preceding the day of observation calibrated for a seasonal trend with ITU-R foF2 predictions. The hourly deviation DNmF2 is defined as the logarithm of ratio of $\mathrm{NmF} 2 / \mathrm{NmF} 2$ med. A segmented logarithmic scale of the ionospheric weather index, $W$, is introduced, so that $W= \pm 1$ refers to the quiet state, $W= \pm 2$ to a moderate disturbance, $W= \pm 3$ to the ionospheric storm, and $W= \pm 4$ to the extreme or anomalous conditions. The catalog of the ionospheric disturbances for $W$ exceeding \pm 2 at least during 3 consecutive hours is produced and presented online at the SRC and IZMIRAN web pages. It is found that the moderate disturbance is a prevailing state of the ionospheric weather for all stations. The stormy conditions comprise 1 to $20 \%$ of the times which occur more frequently at high latitudes, by night, during equinox and winter.
\end{abstract}

Keywords. Ionosphere (Ionospheric irregularities; Modeling and forecasting)

Correspondence to: T. L. Gulyaeva

(tamara@izmiran.troitsk.ru)

\section{Introduction}

The state of the ionosphere is determined by superposition of the regular changes and stochastic variations of the ionospheric parameters. The regular variations are represented by day-to-night, seasonal and solar cycle changes according to solar ionizing flux, sunlight conditions at different geodetic locations, the relation between geodetic and geomagnetic coordinates, the state of the magnetosphere and neutral atmosphere. The solar activity impact is normally defined by global solar indices, like the solar $10.7 \mathrm{~cm}$ radio flux, F10.7, and the sunspot number, Rz. The short-term perturbations vary from a few seconds to a few hours, induced by the solar flares, the solar wind, the coronal mass ejection, affecting the Earth's magnetosphere, plasmasphere and ionosphere. Relevant estimates of spatial and temporal variability of the ionosphere over the different time scales have been made with the peak electron density (Forbes et al., 2000; Rishbeth and Mendillo, 2001; Fotiadis et al., 2004; Fotiadis and Kouris, 2006).

The peak electron density $\mathrm{NmF} 2, \mathrm{~m}^{-3}$, related to the $\mathrm{F} 2$ layer critical frequency foF2, MHz: $\mathrm{NmF} 2=1.24 \times 10^{10} \times$ $(\mathrm{foF} 2)^{2}$, is a more sensitive parameter to characterize the variability of the ionosphere than the other ionospheric characteristics. NmF2 varies by an order of magnitude while the ionospheric heights are subject to variations that are not greater than a factor of two. The foF2 parameter is supplied by the worldwide network of ionosondes made lately accessible via Internet (Reinisch et al., 2004).

The spatial, diurnal, seasonal and solar activity variations of $\mathrm{NmF} 2$ are well represented by the ITU-R maps (CCIR, 1990). Apart from these monthly average variations the daily asssessment and forecast of the ionosphere variability are required for many applications. The negative or positive percentage deviation of the current value of foF 2 from the quiet background value can serve as an "ionospheric activity" AIindex, characterizing a measure of the ionosphere disturbance (Kutiev and Muchtarov, 2001; Bremer et al., 2006).

Published by Copernicus Publications on behalf of the European Geosciences Union. 
Table 1. Percentage of foF2 storm times and monthly standard deviation of foF2, MHz, during 2006.

\begin{tabular}{|c|c|c|c|c|c|c|c|c|c|c|c|c|}
\hline Station & Jan & Feb & Mar & Apr & May & Jun & Jul & Aug & Sep & Oct & Nov & Dec \\
\hline Tromso & 25 & 25 & 21 & 19 & 4 & 3 & 4 & 7 & 16 & 51 & 16 & 18 \\
\hline $\begin{array}{l}70 \mathrm{~N}, 19 \mathrm{E} \\
\text { Sodankyla }\end{array}$ & $\begin{array}{l}.63 \\
15\end{array}$ & $\begin{array}{l}.72 \\
21\end{array}$ & $\begin{array}{l}.62 \\
19\end{array}$ & $\begin{array}{l}.59 \\
21\end{array}$ & .40 & $\begin{array}{l}.40 \\
1\end{array}$ & .44 & .52 & $\begin{array}{l}.51 \\
16\end{array}$ & $\begin{array}{l}.66 \\
17\end{array}$ & $\begin{array}{l}.71 \\
14\end{array}$ & $\begin{array}{l}.64 \\
13\end{array}$ \\
\hline $\begin{array}{l}67 \mathrm{~N}, 27 \mathrm{E} \\
\text { Salekhard }\end{array}$ & $\begin{array}{l}.46 \\
11\end{array}$ & $\begin{array}{l}.49 \\
12\end{array}$ & $\begin{array}{l}.41 \\
20\end{array}$ & $\begin{array}{l}.41 \\
25\end{array}$ & $\begin{array}{l}.31 \\
12\end{array}$ & .38 & .31 & $\begin{array}{l}.45 \\
11\end{array}$ & $\begin{array}{l}.46 \\
13\end{array}$ & $\begin{array}{l}.50 \\
12\end{array}$ & $\begin{array}{l}.48 \\
19\end{array}$ & $\begin{array}{l}.42 \\
24\end{array}$ \\
\hline $\begin{array}{l}66 \mathrm{~N}, 66 \mathrm{E} \\
\text { Magadan }\end{array}$ & .46 & $\begin{array}{l}.46 \\
18\end{array}$ & .44 & $\begin{array}{l}.52 \\
22\end{array}$ & $\begin{array}{l}.41 \\
17\end{array}$ & .52 & .65 & $\begin{array}{l}.37 \\
12\end{array}$ & .39 & $\begin{array}{l}.44 \\
17\end{array}$ & $\begin{array}{l}.47 \\
18\end{array}$ & $\begin{array}{l}.47 \\
17\end{array}$ \\
\hline $\begin{array}{l}60 \mathrm{~N}, 151 \mathrm{E} \\
\text { Juliusruh }\end{array}$ & $\begin{array}{l}.40 \\
17\end{array}$ & $\begin{array}{l}.43 \\
10\end{array}$ & $\begin{array}{l}40 \\
13\end{array}$ & $\begin{array}{l}46 \\
13\end{array}$ & .49 & 6 & 2 & .39 & .37 & .44 & .48 & .50 \\
\hline $\begin{array}{l}55 \mathrm{~N}, 13 \mathrm{E} \\
\text { Moscow }\end{array}$ & .39 & .40 & .34 & $\begin{array}{l}.32 \\
17\end{array}$ & .34 & .49 & .46 & .44 & .30 & .35 & .32 & $\begin{array}{l}.32 \\
11\end{array}$ \\
\hline $\begin{array}{l}55 \mathrm{~N}, 37 \mathrm{E} \\
\text { Fairford }\end{array}$ & 6 & 3 & .29 & $\begin{array}{l}.38 \\
12\end{array}$ & $\begin{array}{l}.31 \\
10\end{array}$ & $\begin{array}{l}.50 \\
10\end{array}$ & .77 & $\begin{array}{l}.50 \\
10\end{array}$ & .28 & .36 & .37 & .41 \\
\hline $\begin{array}{l}52 \mathrm{~N},-02 \mathrm{E} \\
\text { Chilton }\end{array}$ & $\begin{array}{l}.34 \\
9\end{array}$ & $\begin{array}{l}.34 \\
11\end{array}$ & .34 & $\begin{array}{l}.29 \\
13\end{array}$ & $\begin{array}{l}.43 \\
11\end{array}$ & .75 & $\begin{array}{l}.52 \\
11\end{array}$ & $\begin{array}{l}.51 \\
10\end{array}$ & .33 & $\begin{array}{l}.45 \\
10\end{array}$ & $\begin{array}{l}.35 \\
10\end{array}$ & $\begin{array}{l}.36 \\
9\end{array}$ \\
\hline $\begin{array}{l}51 \mathrm{~N},-01 \mathrm{E} \\
\text { Dourbes }\end{array}$ & .36 & .46 & $\begin{array}{l}.30 \\
12\end{array}$ & $\begin{array}{l}.31 \\
15\end{array}$ & .34 & .84 & .93 & .52 & .32 & .36 & .34 & .54 \\
\hline $\begin{array}{l}50 \mathrm{~N}, 05 \mathrm{E} \\
\text { Pruhonice }\end{array}$ & $\begin{array}{l}.55 \\
10\end{array}$ & .52 & $\begin{array}{l}41 \\
5\end{array}$ & .37 & $\begin{array}{l}.43 \\
6\end{array}$ & $\begin{array}{l}.42 \\
6\end{array}$ & .63 & .50 & .39 & $i_{2}^{.44}$ & $\begin{array}{l}.44 \\
6\end{array}$ & .42 \\
\hline $\begin{array}{l}50 \mathrm{~N}, 15 \mathrm{E} \\
\text { Wakkanai }\end{array}$ & $\begin{array}{l}.44 \\
14\end{array}$ & .43 & .38 & $\begin{array}{l}.39 \\
11\end{array}$ & $\begin{array}{l}.44 \\
6\end{array}$ & .96 & $\begin{array}{l}1.03 \\
5\end{array}$ & .85 & .40 & .47 & $\begin{array}{l}.39 \\
10\end{array}$ & $\begin{array}{l}.42 \\
12\end{array}$ \\
\hline $\begin{array}{l}45 \mathrm{~N}, 142 \mathrm{E} \\
\text { Rome }\end{array}$ & $\begin{array}{l}.44 \\
10\end{array}$ & .49 & .43 & .51 & .64 & $\begin{array}{l}.70 \\
13\end{array}$ & $\begin{array}{l}.57 \\
10\end{array}$ & $\begin{array}{l}.48 \\
13\end{array}$ & .41 & .46 & $\begin{array}{l}.45 \\
10\end{array}$ & $\begin{array}{l}.54 \\
11\end{array}$ \\
\hline $\begin{array}{l}42 \mathrm{~N}, 12 \mathrm{E} \\
\text { Tortosa }\end{array}$ & $\begin{array}{l}.49 \\
10\end{array}$ & $\begin{array}{l}.45 \\
6\end{array}$ &.$^{4}$ & $\begin{array}{l}.48 \\
10\end{array}$ & $\begin{array}{l}.66 \\
11\end{array}$ & $\begin{array}{l}.81 \\
14\end{array}$ & $\begin{array}{l}.84 \\
14\end{array}$ & .71 & .51 & .55 & .49 & $\begin{array}{l}.56 \\
10\end{array}$ \\
\hline $\begin{array}{l}41 \mathrm{~N}, 00 \mathrm{E} \\
\text { San Vito }\end{array}$ & $\begin{array}{l}.60 \\
9\end{array}$ & .55 & .53 & .62 & $\begin{array}{l}.78 \\
6\end{array}$ & $\begin{array}{l}.92 \\
15\end{array}$ & $\begin{array}{l}.91 \\
14\end{array}$ & $\begin{array}{l}.70 \\
13\end{array}$ & .60 & $\begin{array}{l}.66 \\
5\end{array}$ & .51 & $\begin{array}{l}.54 \\
20\end{array}$ \\
\hline $\begin{array}{l}41 \mathrm{~N}, 18 \mathrm{E} \\
\text { Athens }\end{array}$ & $\begin{array}{l}.47 \\
8\end{array}$ & $\begin{array}{l}.44 \\
8\end{array}$ & $\begin{array}{l}.49 \\
13\end{array}$ & .51 & .62 & $\begin{array}{l}.91 \\
12\end{array}$ & $\begin{array}{l}.91 \\
10\end{array}$ & $\begin{array}{l}.72 \\
16\end{array}$ & .51 & .57 & .46 & .44 \\
\hline $\begin{array}{l}38 \mathrm{~N}, 24 \mathrm{E} \\
\text { Arenosillo }\end{array}$ & $\begin{array}{l}.51 \\
9\end{array}$ & .51 & .53 & $\begin{array}{l}.63 \\
11\end{array}$ & .81 & $\begin{array}{l}1.07 \\
15\end{array}$ & $\begin{array}{l}1.01 \\
14\end{array}$ & $\begin{array}{l}.78 \\
13\end{array}$ & $\begin{array}{l}.60 \\
16\end{array}$ & $\begin{array}{l}.65 \\
12\end{array}$ & .48 & .49 \\
\hline $37 \mathrm{~N},-07 \mathrm{E}$ & .57 & .56 & .58 & .67 & & 1.17 & 1.47 & 1.08 & .65 & .68 & .51 & .48 \\
\hline
\end{tabular}

So the defined index, however, does not provide a uniform measure of the negative and positive phases of the ionospheric storm, because positive deviations are deeper than negative ones (Kouris et al., 1999). In particular, the depletion of the peak electron density cannot reach $100 \%$, because a decrease in foF 2 to zero is below the lower limit of the ionosonde sounding frequencies. On the other hand, there is no limit imposed on an increase in foF 2 during the positive phase of the ionospheric storm when the critical frequency could exceed the median value by a few hundreds of percent. To avoid these disproportions the decimal logarithm of the hourly value of $\mathrm{NmF} 2$, normalized by the quiet reference, $\mathrm{NmF} 2 \mathrm{med}$, is taken as a measure of the $\mathrm{NmF} 2$ (or foF2) variability (Gulyaeva, 1996, 2002; Field and Rishbeth, 1997; Fuller-Rowell et al., 2000). In this paper, the logarithmic scale index is introduced and demonstrated during the solar minimum.

For the online assessments and forecast of foF 2 the running median for the $27(28,30$, etc.) preceding days is taken as a sliding reference (Gulyaeva, 2002; Bremer et al., 2006; Mikhailov et al., 2007). Though a similar median, but centered on the day of observation, is more representative than the median for the past period of days the "centered" median is not accessible until two weeks after the day of observation. To overcome the seasonal deficiency of the median for the past period, a special procedure is applied below based on a seasonal trend of ITU-R (CCIR, 1990) the foF2 predictions.

An empirical approach based on statistical methods of foF 2 analysis is applied in most of the modern methods of the ionospheric weather assessment and forecast (Kutiev and Muchtarov, 2001; Stanislawska and Zbyszynski, 2001, 2002; Koutroumbas and Belehaki, 2005; Mikhailov et al., 2007). These methods would gain from the reconstruction of gaps in the ionosonde observations (Francis et al., 2001; Stanislawska and Zbyszynski, 2002)that were missed due to the presence of the sporadic E layer, F-spread phenomena, absorption and other physical or technical reasons. In this paper the method for cloning missed foF 2 data is proposed to fill the gaps in the ionosonde observations. The results of its application for the derivation of the ionospheric weather index and disturbed periods are discussed below. 


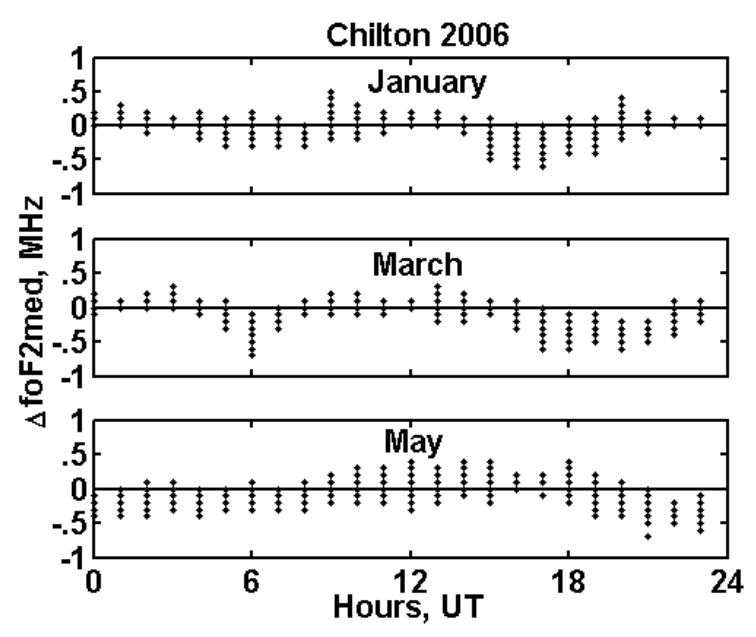

Fig. 1. Bias of the median for 27 preceding days and the 27-day median centered on a given day calculated from foF 2 critical frequency at Chilton (winter - January, equinox - March, summer May 2006).

\section{Data and method of analysis}

The ground-based ionosonde observations available via the Internet have been employed in this study. Daily-hourly values of foF 2 of 16 ionosondes over the range of geodetic latitudes $10^{\circ} \mathrm{W}$ to $150^{\circ} \mathrm{E}$, geodetic longitudes $37^{\circ} \mathrm{N}$ to $70^{\circ} \mathrm{N}$, during the solar minimum, 2006, are used for the analysis (Table 1). The data series consist of 150000 observations of foF2, except for the missed data which could vary from $1 \%$ at mid-latitudes to $50 \%$ at high latitudes, dominating by nighttime during the winter months and at the magnetospheric storms.

The logarithmic scale of the deviations is presented as a logarithm of the ratio of the current hourly value of $\mathrm{NmF} 2$ to the quiet background values $\mathrm{NmF} 2 \mathrm{med}$ :

$\mathrm{DNmF} 2=\log (\mathrm{NmF} 2 / \mathrm{NmF} 2 \mathrm{med})$.

The sign of DNmF2 specifies the positive or negative phase of the ionospheric perturbation.

A "sliding reference" $\mathrm{NmF} 2 \mathrm{med}$ is defined as the timecorresponding median of 27 days preceding the given day of observation (which means in our case that foF2 data for December 2005 have also been used for the median derivation). We assume that the period of 27 days corresponding to the solar rotation yields median values that might also be valid for day 28. This appears to be a reasonable solution for the forecasting purposes, since one has a reference value one day in advance as distinct from the monthly median available only after the month has passed. However, these reference values are more representative for the day centered at the 27 day period, so there is a seasonal delay in the produced "past median" as compared with the actual running median.

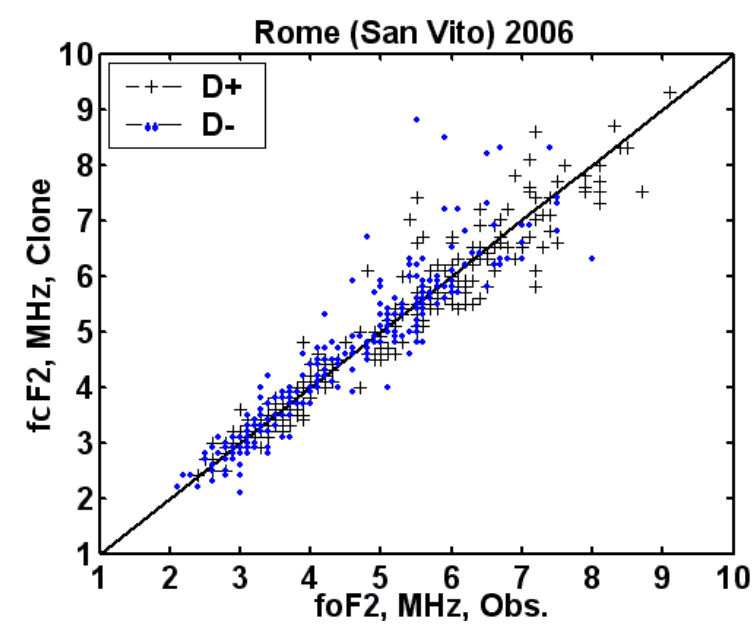

Fig. 2. Comparison of cloned fcF2 data at Rome produced from the parent observations at San Vito with actually observed foF2 data at Rome for the 1-monthly positive most disturbed day and the 1monthly negative most disturbed day during all the months of 2006.

Bias of the 27-day "past median" from the 27-day "centered median" for 3 seasons at Chilton (winter - January, equinox - March, summer - May 2006) is shown in Fig. 1. There are some cases of equal bias shown by the same point. It is evident that the bias can exceed $0.5 \mathrm{MHz}$ capable of distorting the estimates of variability of foF2 with Eq. (1), particularly at nighttime at solar minimum when the observed foF 2 is close to $2 \mathrm{MHz}$. To compensate for a seasonal trend in the "past" reference value we have used a month-to-month variation of foF2 provided by the ITU-R (CCIR, 1990) prediction. Using the ratio of NmF2 from the ITU-R map to the observed $\mathrm{NmF} 2 \mathrm{med}$ for the preceding month at a specified location and level of solar activity, we extrapolate this ratio with the ITU-R seasonal trend of foF 2 for a relative change in the observed reference value to the day of two weeks ahead which provides a calibration coefficient applied to the "past" median.

\section{Cloning missed ionosonde observations}

Our present technique for nowcasting of the ionosphere variability would be more successful if gaps in the ionosonde observations might be reconstructed with a relevant procedure, particularly during nighttime and geomagnetic storms.

We introduce the process of cloning a missed value at the $i-$ th station $(\mathrm{NmF} 2 \mathrm{i})$ using the median $(\mathrm{NmF} 2$ medi) and available observation of $\mathrm{NmF} 2 \mathrm{j}$ with the median $(\mathrm{NmF} 2$ medj) at another station:

$\mathrm{NmF} 2 \mathrm{i}=\mathrm{NmF} 2 \mathrm{j} \times(\mathrm{NmF} 2 \mathrm{medi} / \mathrm{NmF} 2 \mathrm{medj})$.

In Fig. 2 the results are presented for cloned fcF2 data at Rome using parent observations at San Vito selected for 
Table 2. Mean value of observed foF2 and cloned fcF2 (MHz) at 9 stations (parent station is indicated) for monthly 1 positive disturbed day (+) and 1 negative disturbed day (-) during all the months of 2006. Standard deviation between cloned fcF2 and observed foF2 data, s.d. Distance at altitude of $300 \mathrm{~km}$ above the ground between the clone site and parent site, D. Number of considered hourly values, h.

\begin{tabular}{lllllllllll}
\hline $\begin{array}{l}\text { Clone site } \\
\text { (Parent) }\end{array}$ & $\begin{array}{l}\text { Lat. } \\
\text { deg. }\end{array}$ & $\begin{array}{l}\mathrm{D}, \\
\mathrm{km}\end{array}$ & $\begin{array}{l}\text { Data }+ \\
\mathrm{h}\end{array}$ & $\begin{array}{l}\text { foF2+ } \\
\text { Obs. }\end{array}$ & $\begin{array}{l}\mathrm{fcF}+ \\
\text { Clone }\end{array}$ & $\begin{array}{l}\text { s.d.+ } \\
\mathrm{MHz}\end{array}$ & $\begin{array}{l}\text { Data } \\
\text { h- }\end{array}$ & $\begin{array}{l}\text { foF2- } \\
\text { Obs. }\end{array}$ & $\begin{array}{l}\text { fcF2- } \\
\text { Clone }\end{array}$ & $\begin{array}{l}\text { s.d.- } \\
\mathrm{MHz}\end{array}$ \\
\hline Ela(Tor) & 37.1 & 781 & 269 & 5.45 & 5.49 & .70 & 260 & 4.90 & 4.88 & .66 \\
Ate(Vit) & 38.0 & 691 & 259 & 5.26 & 5.32 & .54 & 239 & 4.80 & 4.70 & .58 \\
Rom(Vit) & 41.8 & 393 & 227 & 5.07 & 5.04 & .43 & 232 & 4.50 & 4.57 & .52 \\
Pru(Jul) & 50.0 & 542 & 276 & 4.82 & 4.78 & .59 & 248 & 4.27 & 4.17 & .70 \\
Chi(Fai) & 51.6 & 38 & 285 & 4.75 & 4.70 & .42 & 278 & 4.06 & 3.94 & .71 \\
Jul(Dou) & 54.6 & 467 & 286 & 4.50 & 4.57 & .50 & 280 & 3.86 & 3.90 & .49 \\
Mos(Pru) & 55.5 & 1713 & 237 & 4.50 & 4.60 & .80 & 249 & 3.80 & 4.02 & .82 \\
Mag(Wak) & 60.0 & 1817 & 226 & 3.96 & 4.07 & .59 & 233 & 3.92 & 4.04 & .69 \\
Sod(Tro) & 67.4 & 419 & 197 & 3.97 & 3.97 & .64 & 209 & 3.51 & 3.50 & .43 \\
\hline
\end{tabular}

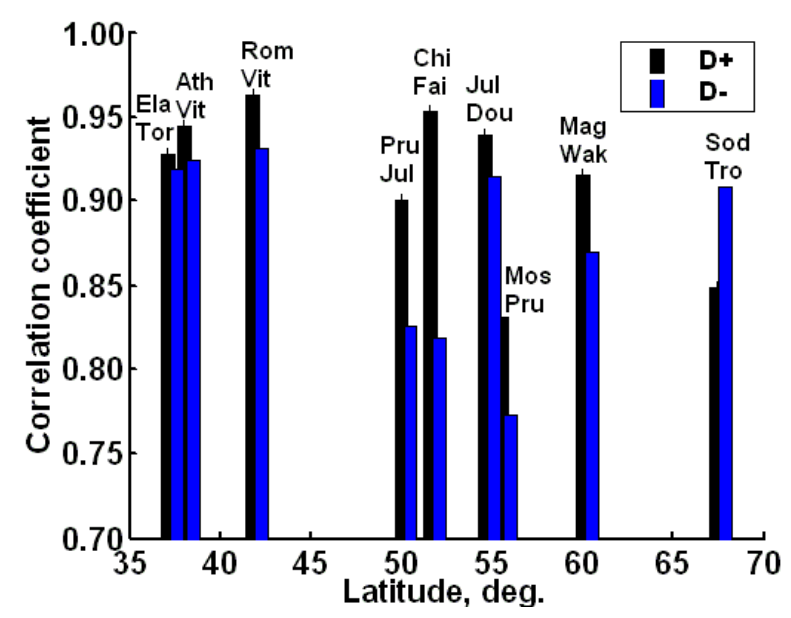

Fig. 3. Correlation coefficient between cloned and observed F2 layer critical frequency at clone site (upper abbreviation) deduced from parent site (lower abbreviation) at geodetic latitude of clone site.

the 1-monthly positive most disturbed day (black crosses) and the 1-negative most disturbed day (blue points) of each month during 2006. Listing of the ionospheric disturbed and quiet days is available at the IDCE web site (Stanislawska et al., 1999). An artificial gap in the foF2 data for selected disturbed days at Rome was simulated for the estimate purposes. A calibrated running 27-day median for the preceding period served as NmF2medi for Rome, and NmF2medj for San Vito. The cloned results fcF2 are shown against the observed foF2 data at Rome.

Similar analysis has been performed with the data of 9 pairs of stations listed in Table 2 using selected positive and negative disturbed days of 2006 . Here the mean of the observed foF 2 and the cloned fcF2, and the standard deviation of the regression of $\mathrm{fcF} 2$ on foF 2 for the clone station are given. While the magnitude of the mean values does not exceed $5.5 \mathrm{MHz}$ the daily-hourly values considered during the year vary from 2 to $12 \mathrm{MHz}$. The geodetic latitude of the clone station and the distance in $\mathrm{km}$ between the clone site and the parent site (given in the brackets) at the altitude of $300 \mathrm{~km}$ above the Earth are also provided. The number of considered hourly values varies from station to station, since the number of observed foF 2 at the clone site is limited by the gaps in observations. It is clear from Table 2 that the mean values derived from the data spread over a year demonstrate greater results for the positive disturbed days than for the reduced critical frequencies at the negative phase of the ionospheric disturbances. Mean values are reduced from middle to high latitudes, according to the global morphology of the peak electron density. The standard deviation for selected days over the year is comparable with the monthly standard deviation presented in Table 1.

The correlation coefficient between cloned fcF2 and observed foF2 at selected locations for the arrays presented in Table 2 is shown in Fig. 3. The correlation coefficient exceeds 0.75 in all cases and appears to be independent of the distance between the clone site and the parent site given in Table 2 often exceeding the correlation distance specified by Stanislawska et al. (1997). The correlation coefficient is greater for the positive disturbed days (black bars) than for the negative disturbed days (blue bars), except for the highlatitude station Sodankyla, where the effects of two classes of disturbance will be discussed below. The procedure for reconstruction of gaps in foF2 observations with Eq. (2) is applied for the set of stations since December 2005 and the results are presented at the web page of IZMIRAN. 


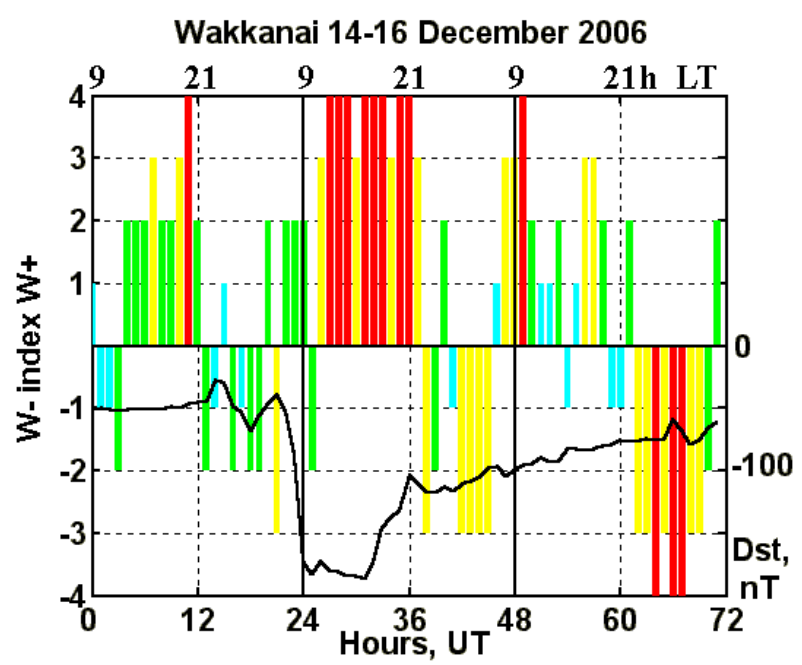

Fig. 4. The ionospheric weather index at Wakkanai during 3 days of ionospheric storm on 14-16 December 2006. $W= \pm 1$ (blue), $W= \pm 2$ (green), $W= \pm 3$ (yellow), $W= \pm 4$ (red). Equatorial $\mathrm{D}_{s} t$ index (bottom panel).

Table 3. Ionospheric weather index, relevant thresholds of logarithmic deviations and corresponding percentage changes in the F2 layer critical frequency foF2.

\begin{tabular}{lll}
\hline$W$ index & $\mathrm{DN}=\log \left(\mathrm{Nm} / \mathrm{Nm}^{*}\right)$ & $\mathrm{P} \%$ \\
\hline 4 & $0.301<\mathrm{DN}$ & $+200 \%<\mathrm{P}$ \\
3 & $0.155<\mathrm{DN} \leq 0.301$ & $+43 \%<\mathrm{P} \leq+200 \%$ \\
2 & $0.046<\mathrm{DN} \leq 0.155$ & $+11 \%<\mathrm{P} \leq+43 \%$ \\
1 & $0<\mathrm{DN} \leq 0.046$ & $0<\mathrm{P} \leq+11 \%$ \\
-1 & $-0.046 \leq \mathrm{DN}<0$ & $-10 \% \leq \mathrm{P}<0$ \\
-2 & $-0.155 \leq \mathrm{DN}<-0.046$ & $-30 \% \leq \mathrm{P}<-10 \%$ \\
-3 & $-0.301 \leq \mathrm{DN}<-0.155$ & $-50 \% \leq \mathrm{P}<-30 \%$ \\
-4 & $\mathrm{DN}<-0.301$ & $\mathrm{P}<-50 \%$ \\
\hline
\end{tabular}

\section{Logarithmic deviations and ionospheric weather in- dex}

For indexing the ionosphere variability similar to geomagnetic k-indices (Menveielle and Berthelier, 1991) we introduce the ionospheric weather index $W$ specified in Table 3. We use a non-uniform logarithmic scale similar to Gulyaeva (1996). The intervals for the positive and negative deviation of DNmF2 are equal to each other but the relevant threshold of the changes in foF 2 would be different for the negative and positive deviations. Index $W= \pm 1$ is used for the quiet state, $W= \pm 2$ for the moderate disturbance, $W= \pm 3$ for the ionospheric storm, and $W= \pm 4$ for the extreme or anomalous conditions. Criteria for selection of such intervals are based on the conventional evaluation of the negative ionospheric

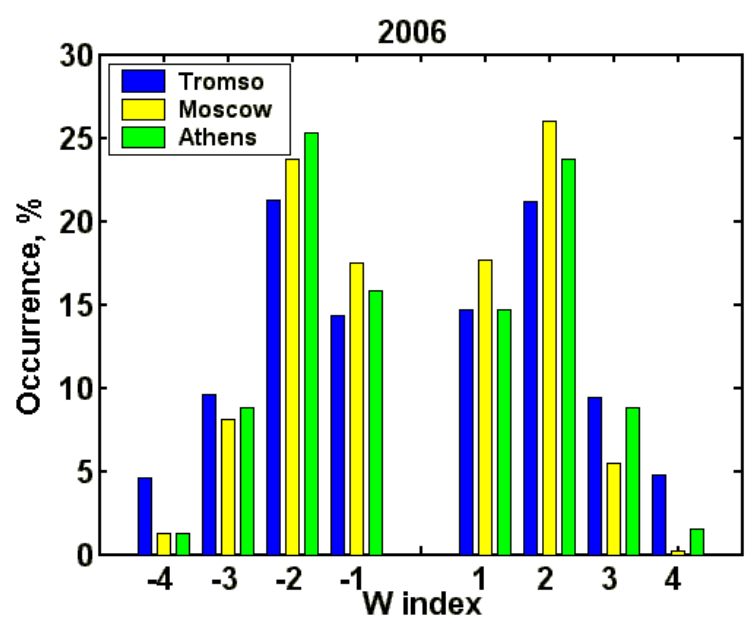

Fig. 5. The occurrence rate of the ionospheric weather index at high latitude (Tromso), mid-latitude (Moscow) and low-midlatitude (Athens) during the year of solar minimum.

foF2 deviation within $[0,-10 \%]$ from the quiet reference for the quiet state, $[-10,-30 \%]$ for the moderate disturbance, $[-30,-50 \%]$ for the ionospheric storm, and a depletion of foF2 greater than $-50 \%$ for the extreme conditions.

The $W$ index produced for the period of 14 to 16 December 2006 for Wakkanai is shown in Fig. 4, where the $\mathrm{D}_{s} t$ storm onset occurred at 09:00 h of local time (00:00 h UT) on 15 December. The ionosphere response to the magnetic storm onset during the local daytime is typical for midlatitude (Buonsanto, 1999). Here the positive phase of the ionospheric storm is observed during the main phase of the geomagnetic storm followed by the negative phase at the local night on 15 December, the next positive phase early on 16 December and an appreciable negative phase at the local nighttime on 16 to 17 December. It is evident from this figure that the weather index $W$ is capable of displaying characteristics which represent the different states of the ionospheric weather.

Figure 5 presents the occurrence rate of the $W$ index at high-latitude (Tromso), mid-latitude (Moscow) and low-midlatitude (Athens). The dominant state of the ionospheric weather is $W= \pm 2$ (moderate disturbance) at all latitudes. The storm time percentage occurrence is growing towards the high latitude $(W= \pm 3$ and $W= \pm 4)$.

\section{Ionospheric disturbed periods}

Since 1997, the ionospheric disturbed periods for selected ionosondes in Europe and Russia are permanently calculated by one of the co-authors (TLG) for the Ionospheric Despatch Centre in Europe, IDCE, Warsaw (http://www.cbk.waw.pl), and at IZMIRAN since December 2005 (http://www.izmiran. ru/ionosphere/weather/). The DNmF2 disturbed periods are 


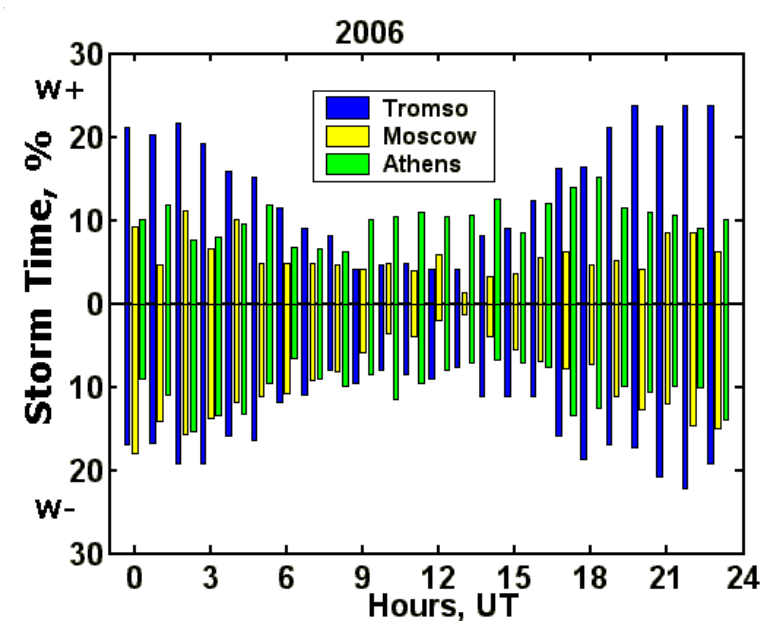

Fig. 6. Diurnal variation of the percentage of the ionospheric storm times at the solar minimum year for the negative ionospheric storms $(W \leq-3)$ and positive ionospheric storms $(W \geq+3)$ at three stations shown in Fig. 5.

specified for the positive and negative ionospheric disturbances at least of $3 \mathrm{~h}$ in duration. The above defined ionospheric weather index $W$ provides new criteria for selecting the ionospheric disturbed periods.

Earlier catalog of disturbed periods has been based on the selection of $3 \mathrm{~h}$ or longer for the mean relative deviation of $\mathrm{NmF} 2$ greater than $\pm 40 \%$ which corresponds to the requirement for foF2 deviation to exceed the monthly median by $\pm 20 \%$ (Kouris et al., 1998). Such an analysis could be performed on a monthly basis upon the end of each month when the monthly median could be obtained.

An online daily update of the catalog of disturbed periods has been processed since December 2005 based on proposed new technology, including cloning of missed ionospheric observation, derivation of the calibrated 27-day running median for the past period, calculation of the logarithmic deviation from the quiet reference and specifying the weather $W$ index. Then a selection of $3 \mathrm{~h}$ or longer disturbed periods is made with the criteria of the average $W$ index less than -2 for the negative disturbance or $W$ index greater than +2 for the positive event.

Table 1 provides the monthly summary of stormy times, h, for each station during the year 2006. The monthly standard deviation from the quiet reference values of foF $2, \mathrm{MHz}$, is also presented as a measure of the stochastic variability of the ionosphere. We note that the monthly standard deviation is typically around $0.5 \mathrm{MHz}$, though it can reach $1 \mathrm{MHz}$ sometimes. It follows from Table 1 that during the solar minimum the ionospheric storm times can comprise 1 to $20 \%$ of the hourly values per month, growing towards the high latitudes. At high latitudes the ionosphere is more disturbed during the equinox and winter months while the summertime dominant disturbances can occur at the lower latitudes.
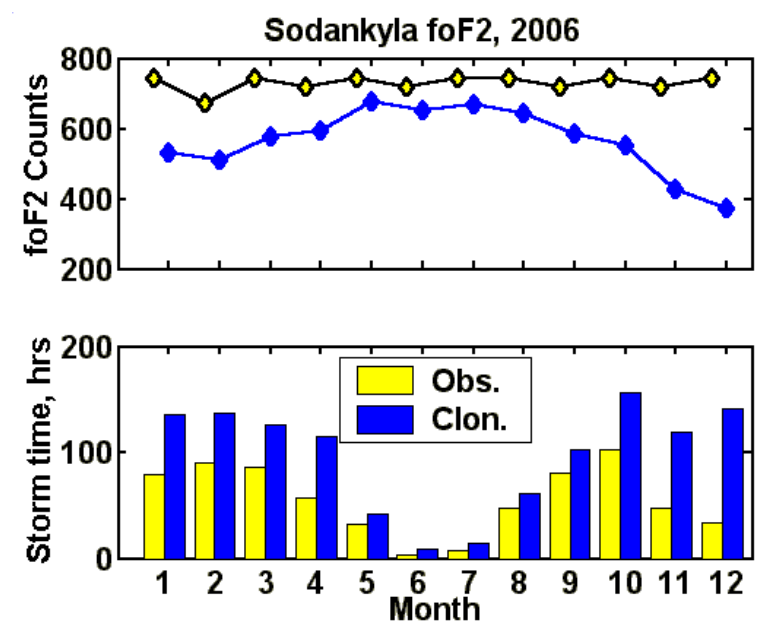

Fig. 7. Seasonal variation of monthly counts of the ionospheric storm times at Sodankyla (lower panel) for actually observed data sets and complete monthly data, including cloned fcF2 values filling the gaps in the observations. The actual number of observed hourly values of foF 2 and the complete monthly counts of hours (upper panel).

The diurnal variation of the percentage of the storm times for the whole year 2006 is illustrated in Fig. 6 for the negative events $(W \leq-3)$ and positive ionospheric disturbed periods $(W \geq+3)$ at the same three sites, as shown in Fig. 5. It is evident from Fig. 6 that the stormy times are growing towards the night at high latitude. There is no daily preference for the positive storm times at low mid latitude but the negative storm times are growing towards the night.

Finally, the seasonal counts of storm times at Sodankyla are demonstrated in Fig. 7 (lower panel) for actually observed data sets and complete monthly data, including cloned fcF2-value filling the gaps in the observations. The upper panel illustrates the actual number of observed hourly values of foF2 (lower curve) and the complete monthly counts of hours. The complete data set of foF2 yields a greater number of storm time hours; in particular, it has increased by a few times for November and December when many values of ionosonde observations are missing and replaced by a descriptive or qualifying letter during the winter nighttimes at auroral latitudes during $24 \mathrm{~h}$ per day.

\section{Conclusions}

Information technology for quantitative estimates of the ionospheric variability is described. It is based on the ionosonde observations of the F2 layer critical frequency, foF2. Missing ionosonde observations are reconstructed by cloning data of another station. This process assumes proportionality of the disturbance level regarding quiet background values for parent and cloned data. 
The quiet reference is determined as a running dailyhourly median for 27 days preceding the day of observation calibrated for the seasonal trend with ITU-R foF2 predictions. The hourly deviation DNmF2 is defined as the logarithm of the ratio of the actual hourly value of $\mathrm{NmF} 2$ (deduced from foF2) to the quiet reference.

A segmented logarithmic scale of the ionospheric weather index, $W$, is introduced so that $W= \pm 1$ for the quiet state, $W= \pm 2$ for the moderate disturbance, $W= \pm 3$ for the ionospheric storm, and $W= \pm 4$ for the extreme or anomalous conditions.

Data of 16 ionospheric stations at latitude range $37^{\circ}$ to $70^{\circ} \mathrm{N}$, longitudes of $10^{\circ} \mathrm{W}$ to $150^{\circ} \mathrm{E}$, during the solar minimum, 2006 have been analyzed for testing the proposed algorithms. The correlation coefficient of cloned data with observed data proved to be greater than 0.75 for the positive disturbed days and the negative disturbed days throughout the year at solar minimum, independent of a distance between the clone site and parent site. Catalog of the ionospheric disturbances at least $3 \mathrm{~h}$ in duration for the index $W$ exceeding \pm 2 is produced and presented online at the SRC and IZMIRAN web pages. It is found that the moderate disturbance $(W=+2)$ is a prevailing state of the ionospheric weather for all stations. The stormy conditions comprise 1 to $20 \%$ of times which occur more frequently at high latitudes, by night, during equinox and winter.

Acknowledgements. The foF2 data are provided via Internet from SEC and NGDC, NOAA, Boulder, CO, USA; IDCE, Warsaw, Poland; WDC-C1, Oxford, UK; DIAS, Athens, Greece; SGO, Sodankyla, Finland; IZMIRAN, Moscow, Russia; WDC for Ionosphere, NICT, Tokyo, Japan. The authors are thankful to referees and editor M. Pinnock for helpful helpful comments and suggestions. This study was conducted under RAS-PAS cooperation and partly supported by European COST724 and COST296 Projects.

Topical Editor M. Pinnock thanks three anonymous referees for their help in evaluating this paper.

\section{References}

Bremer, J., Cander, Lj. R., Mielich, J., and Stamper, R.: Derivation and test of ionospheric activity indices from real-time ionosonde observations in the European region. J. Atmos. Sol.-Terr. Phy., 68, 2075-2090, 2006.

Buonsanto, M. J.: Ionospheric storms - a review, Space Sci. Rev., 88, 563-601, 1999.

CCIR Atlas of Ionospheric Characteristics: Comite Consultatif International des Radiocommunications, Rept. 340, Geneva, 1990.

Field, P. R. and Rishbeth, H.: The response of ionospheric F2-layer to geomagnetic activity: an analysis of worldwide data, J. Atmos. Sol.-Terr. Phy., 59, 2, 163-180, 1997.

Forbes, J. M., Palo, S. E., and Zhang, X.: Variability of the ionosphere, J. Atmos. Solar-Terr. Phys., 62, 685-693, 2000.

Fotiadis, D. N., Kouris, S. S., Romano, V., and Zolesi, B.: Climatology of ionospheric F-Region disturbances, Ann. Geophys., 47, 1311-1323, 2004, http://www.ann-geophys.net/47/1311/2004/.
Fotiadis, D. N. and Kouris, S. S.: Capturing the morphology of long-duration negative ionospheric disturbances using an empirical pattern recognition method, Radio Sci., 41, RS6012, doi:10.1029/2005RS003395, 2006.

Francis, N. M., Brown, A. G., Cannon, P. S., and Broomhead, D. S.: Prediction of the hourly ionospheric parameter foF2 using a novel nonlinear interpolation technique to cope with missing data points, J. Geophys. Res., 106, 30 077-30 084, 2001.

Fuller-Rowell, T. J., Codrescu, M. V., and Wilkinson, P.: Quantitative modeling of the ionospheric response to geomagnetic activity, Ann. Geophys., 18, 766-781, 2000, http://www.ann-geophys.net/18/766/2000/.

Gulyaeva ,T. L.: Logarithmic scale of the ionosphere disturbances, Geomagn. Aeronomy, 36, 1, 115-118, 1996.

Gulyaeva, T. L.: Daily assessment of the ionosphere variability, Acta Geod. Geophys. Hungarica, 37(2-3), 303-308, 2002.

Kouris, S. S., Fotiadis, D. N., and Xenos, Th. D.: Some remarks on the day-to-day variability of foF2 and M(3000)F2, Adv. Space Res., 22, 6, 873-876, 1998.

Kouris, S. S., Fotiadis, D. N., and Zolesi, B.: Specifications of the Fregion variations for quiet and disturbed conditions, Phys. Chem. Earth, Part C, 24(4), 321-327, 1999.

Koutroumbas, K. and Belehaki, A.: One-step ahead prediction of foF2 using time series forecasting techniques. Ann. Geophys., 23, 3035-3042, 2005,

http://www.ann-geophys.net/23/3035/2005/.

Kutiev, I. and Muchtarov, P.: Modeling of midlatitude F-region response to geomagnetic activity, J. Geophys. Res., 106, $15501-$ $15509,2001$.

Menveielle, M. and Berthelier, A.: The K-derived planetary indices: description and availability, Rev. Geophys., 29(3), 415432, 1991.

Mikhailov, A. V., Depuev, V. Kh., and Depueva, A. Kh.: Short-term foF2 forecast: present day state of art, edited by: Lilensten, J.: Ionospheric Weather, Astrophysics and Space Science Library, 344, 156-167, 2007.

Reinisch, B. W., Galkin, I. A., Khmyrov, G., Kozlov, A., and Kitrosser, D. F.: Automated collection and dissemination of ionospheric data from the digisonde network, Adv. Radio Sci., 2, 241-247, 2004, http://www.adv-radio-sci.net/2/241/2004/.

Rishbeth, H. and Mendillo, M.: Patterns of F2-layer variability, J. Atmos. Sol.-Terr. Phy., 63, 1661-1680, 2001.

Stanislawska, I., Juchnikowski, G., and Gulyaeva, T. L.: Correlation distances based on ionospheric and geomagnetic catalogues, Proc. STP-V Workshop, Hitachi, Japan, 387-390, 1997.

Stanislawska I., Gulyaeva T. L., and Hanbaba, R.: Ionospheric Despatch Centre in Europe, Phys. Chem. Earth (C), 24, 355-357, 1999.

Stanislawska, I. and Zbyszynski, Z.: Forecasting of the ionospheric quiet and disturbed foF2 values at single location, Radio Sci., 36, 1065-1071, 2001.

Stanislawska, I. and Zbyszynski, Z.: Forecasting of ionospheric characteristics during quiet and disturbed conditions, Ann. Geophys., 45, 169-176, 2002, http://www.ann-geophys.net/45/169/2002/. 